\title{
DRIVERS FOR OUTSIDE-IN PORT HINTERLAND INTEGRATION IN LATIN AMERICA: THE CASE OF VERACRUZ, MEXICO
}

This is the pre-published version of the text. The final published paper can be found at:

Wilmsmeier, G., Monios, J., Rodrigue, J-P. (2015). Drivers for Outside-In port hinterland integration in Latin America: the case of Veracruz, Mexico. Research in Transportation Business \& Management. 14: 34-43.

DOI: 10.1016/j.rtbm.2014.10.013

\begin{abstract}
This paper examines the spatial and institutional characteristics of inland port development in Latin America, through an analysis of a detailed case study of the port of Veracruz in Mexico. It explores the spatial distribution of seaports and inland ports as well as the issues of customs clearance, rail regulation, cargo security and land acquisition, before discussing conflicting models of development depending on the priorities of inland and port actors. A supplementary aim of the paper is thus to develop a conceptual model of directional development in a geographical context of an emerging economy which traditionally has suffered from the absence of integrated policy frameworks for transport and logistics, leading to a lack of infrastructure investment and several constraints on hinterland accessibility.

Findings reveal that port actors (both port authorities and terminal operators) are being proactive in response to a changing transport and logistics environment, in a setting where railway regulation and cargo security play critical roles in establishing hinterland integration. Reform to customs clearance processes is ongoing to allow more effective container flow management between the port and the hinterland, but the major obstacle to implementing an efficient loop is the fragmentation of the rail sector in Mexico.
\end{abstract}

Keywords: intermodal terminal; container port; rail regulation; customs clearance 


\section{Introduction}

Port geography is increasingly influenced by activities in the hinterland, which comprises the geographical distribution of the port's customer base. The physical separation of production and consumption that characterizes globalized supply chains results in the movement of goods not simply between ports but to and from areas far inland. Ocean shipping costs have decreased substantially in recent times, enabling the cross-subsidization of overland transport; this decrease in the overall door-to-door cost has allowed regions distant from ports to access global trade routes through intermodal links.

Developments in the maritime sector influence the geography of hinterland transport in three key ways: through competition between ports for overlapping hinterlands, by attempts to improve the efficiency of inland transport modes through large intermodal corridors and via efforts on behalf of various actors to integrate supply chains by the setting of inland ports.

Developing an inland port in the hinterland with a high-capacity link to a port can fulfil the aims of both port and inland actors, improving trade access for a region that suffers from poor accessibility to ports while also providing a competitive advantage for the port concerned. Consolidation of flows to provide economies of scale, decreased transport costs through access to main routes and reduced transaction costs through inland access to services such as customs and containerisation are all desirable for inland shippers, while the port benefits from increased traffic flows along this corridor as well as decreased congestion and increased administrative efficiency at the port gate. While such facilities have in the past mostly been planned and built by inland actors (whether cities and regions or private freight operators), ports may also pursue such developments themselves.

While the drivers of port-hinterland integration vary across geographical and economic contexts, these relationships can be conceptualized by contrasting port-driven (Outside-In) and inland-driven (Inside-Out) inland ports (Wilmsmeier et al., 2011 - see section 2). This model highlights the difficulties of port actors extending their influence beyond the port perimeter, as well as enabling the identification of success factors when some ports manage to overcome these challenges.

Moreover, conceptual models to classify and analyse different strategies of inland port development have tended to focus on Europe and the United States (e.g. Rodrigue \& Notteboom 2009; Rodrigue et al. 2010; Monios \& Wilmsmeier 2012). While in recent years some literature on Asia, Africa and Latin America has begun to be published, it remains the case that a geographical understanding of the spatial development of intermodal freight transport in developing economies has been insufficiently developed (Notteboom \& Rodrigue 
2009). In Latin America, port hinterland integration remains in its infancy, both as a field of inquiry ( $\mathrm{Ng}$ et al., 2013) and as an application.

This paper presents a spatial and institutional analysis of inland port development in Mexico, with two primary aims. First, to provide a detailed case study of Outside-In development in order to understand in detail the process through which a port establishes a hinterland subsidiary; and second, to compare Outside-In hinterland integration between developed and developing countries.

\section{The spatial and institutional context of inland port development}

Early models of port development focused primarily on the spatial analysis of freight corridors, such as the "main street" model of Taaffe et al. (1963) and Bird's (1963) “Anyport" model, which were further developed by Rimmer (1967) and Hoyle (1968). Hayuth (1981) developed the concept of load centres that increase their inland penetration and hinterland capture, and Barke (1986) produced a similar model, with an additional focus on decentralisation, whereby some port activities are moved from the port to less congested areas. Van Klink (1998) suggested port city, port area and port region as summaries of previous port models. The rise of port networks was identified as a stage in port development, including logistical control of inland access as a phase of development, particularly related to the integration of activities at non-contiguous sites.

Notteboom and Rodrigue (2005) added a phase of "port regionalisation" to previous models, arguing that the rising importance of inland load centres to port development, particularly the integration of inland terminals to the transport network, was not well addressed. Port regionalisation is defined as a process whereby "market forces and political influences gradually shape regional load centre networks with varying degrees of formal linkages between the nodes of the observed networks" (p.302). According to the port regionalisation concept, logistical integration and network orientation, as well as the globalisation and "terminalisation" of seaports (Slack and Frémont 2005; Rodrigue \& Notteboom, 2009; Notteboom, 2009) explain the geographical and functional expansion of load centres to become "regional load centre networks". Discontinuous hinterlands are supported by logistic zones and inland distribution centres that are connected to the ports by high volume transport corridors.

However, more detailed exploration is required of how port actors (either port authorities or terminal operators) are shaping the process of port regionalisation. There remains a need to understand their motivations and abilities to act, and how these actions are enabled and 
constrained by the structures and processes of inland freight operation and regulation. The early port development literature was focused more on spatial development than actor-centric approaches; while the distinction between port actors has since been made (Heaver et al., 2000; Notteboom \& Winkelmans, 2001; Olivier \& Slack, 2006, Jacobs and Notteboom, 2011; Notteboom et al., 2013; Monios and Wilmsmeier, 2013), insufficient attention has been given to the identification and analysis of different inland development strategies and the actors supporting them (Rodrigue et al., 2010).

Based on the product lifecycle theory and following Schaetzl (1996), Cullinane and Wilmsmeier (2011) argued for "location splitting" as a means to extend the port life cycle when limitations in feasible rationalisation, investment and access are reached. The creation of a subsidiary in the hinterland helps extend the port's commercial reach that is being challenged by inadequacies of the existing port location, operational constraints or increasing competition. The question is whether location splitting can be induced by landside-driven factors as well, such as vertical supply chain integration and transport system regulation (e.g. Heaver et al., 2000; Heaver et al., 2001; Frémont \& Soppé, 2007; Hayuth, 2007; Olivier \& Slack, 2006; Notteboom, 2008).

Notteboom and Rodrigue (2005) characterised inland terminals and load centres as active nodes in shaping the transport chain. Wilmsmeier et al. $(2010,2011)$ argued that missing from the regionalisation model were both the differentiation of drivers of development (e.g. port authority, port terminal, rail operator, public organisation) and the direction (i.e. landdriven vs. sea-driven), thus utilising insights from industrial organisation to examine how different institutional frameworks reveal nuances in the different integration levels between inland ports and seaports. A conceptual approach to inland terminal development was introduced, contrasting Inside-Out development strategies (land-driven e.g. rail operators or public bodies) with those that are pursued Outside-In (sea-driven e.g. port authorities, terminal operators) (Figure 1). While not all sites can be classified solely as one or the other, this broad conceptual distinction highlights conflicting strategies and the importance of port investment if an inland port is to establish successful port container shuttles. 

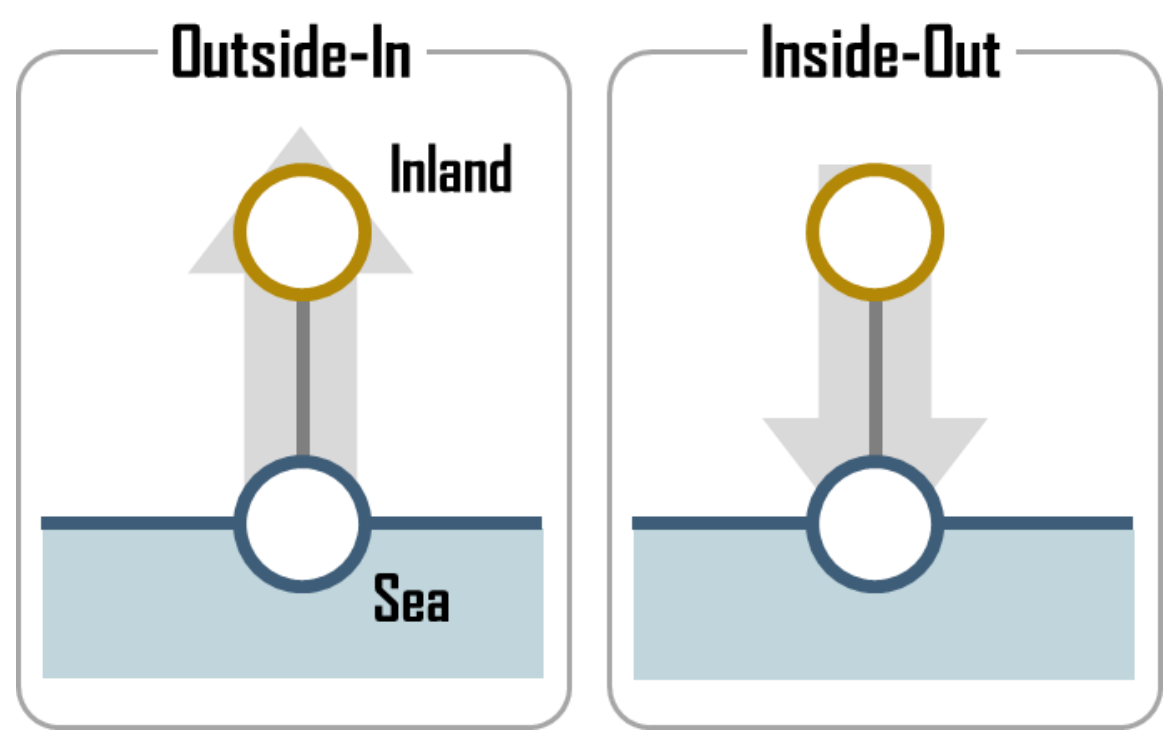

Figure 1 Inside-Out and Outside-In Port / Hinterland Integration

Recent research has shown how spatial development is to a large degree an institutional problem (de Langen \& Chouly, 2004; Van der Horst \& de Langen, 2008; Van der Horst \& Van der Lugt, 2009; Van der Horst \& Van der Lugt, 2011). In focusing on the development process of inland freight facilities in relation to ports, the directional model examines the relation between institutional issues and spatial development. Moreover, different kinds of inland freight facilities specialise in specific functions and exhibit different institutional settings and governance frameworks (e.g. load centre, freight village, inland port, extended gate), producing a diversity of port regionalisation strategies (Monios \& Wilmsmeier, 2012).

In the past, Inside-Out development has been the most dominant because the developers of inland freight facilities are usually real estate developers, cities and regions, transport and logistics operators. Moreover, port actors do not generally possess the institutional capacity to drive developments deep in their hinterlands. This is particularly the case for port authorities (generally working on a public mandate from the city or region), but even private port terminal operators are generally working to a core competency and the institutional structure (as represented by the board of directors who report to the shareholders) is unlikely to be suited to the requirements relating to purchasing land and dealing with the regulatory and other issues of developing a subsidiary in the hinterland. Short-range satellite terminals for overspill functions can be feasible, but load centres hundreds of miles away are not generally compatible with the aims of the port. That is why the Outside-In model requires deeper understanding through a single case study. 
According to the Outside-In model, inland ports are used by seaports as a tool both for securing their hinterland control and overcoming operational problems such as congestion. Like Inside-Out inland ports, the intended functions of such inland ports may cover cargo transhipment from rail to road as well as on-site customs clearance service and bonded warehousing, consolidation and distribution activities (and other low-value-added services).

Port actors (whether port authorities or port terminal operators) have difficulties extending their influence beyond the port perimeter, therefore Outside-In development of inland ports is more challenging. The Outside-In model has been found to be more successful at overcoming operational issues such as congestion, whereas when it is undertaken primarily for strategic reasons such as port competition through hinterland capture, the control over the process is less certain and the result generally less successful (Monios \& Wilmsmeier, 2012). On the other hand, Inside-Out strategies for logistics poles do not always align with the operational or strategic aims of port actors, meaning that while domestic container flows may be attainable, establishing regular shuttles between ports and inland locations for international flows proves difficult, as the port is not motivated to overcome the various operational and institutional difficulties involved.

There is some debate concerning whether Outside-In or Inside-Out development is the most likely model in developed or developing countries (Monios \& Wilmsmeier, 2012; Ng \& Cetin, 2012; Monios \& Wang, 2013). While Outside-In developments are increasingly evident in developed countries, Inside-Out tends to be more common. This is because in developed countries strong institutional settings are often in place to support regional development through transport and logistics initiatives. An in-depth analysis of an Outside-In case in a developing economy is thus required to explore the role of the institutional setting in enabling or constraining such developments.

While the directional model highlights the difficulties of port actors extending their influence beyond the port perimeter, some ports have clearly managed to do so, but limited information is available concerning the major influences and constraints on such strategies. In order to address this research gap, this work investigates a single Outside-In case to examine a port's hinterland development strategy from spatial and institutional perspectives. One of the most successful cases of Outside-In development in the literature is the inland port at Venlo in the Netherlands (Rodrigue et al., 2010; Monios \& Wilmsmeier, 2012; Veenstra et al., 2012). This site was developed by Europe Container Terminals (ECT), a private port terminal operator situated within the port of Rotterdam, and a subsidiary of global port terminal operator Hutchison Port Holdings (HPH). The case study in this paper is also an 
initiative of HPH, who is the main port terminal operator in the port of Veracruz and who has been actively involved in hinterland development strategies. Therefore, it will provide opportunities to compare and contrast strategies pursued by the same terminal operator between developed and developing economies.

The Outside-in approach will be utilised to analyse the Veracruz case from a conceptual perspective, enabling a comparative framework in order to establish whether the spatial and institutional geography of Mexico's intermodal transport development is following patterns observed in more developed inland transport systems. Thus, a supplementary aim of the paper is to develop the conceptual model of directional development in a new geographical context.

\section{The Mexican port system}

Mexico has extensive coastlines on the Pacific Ocean and in the Gulf of Mexico with over 100 ports and their associated terminals. However, the strong integration of Mexico to the American economy through land links and border oriented development, as underlined by the setting of NAFTA in 1992, implied a pattern that was less conducive to port development. Figure 2 provides an overview of the Mexican port system and the owners of the rail infrastructure. 


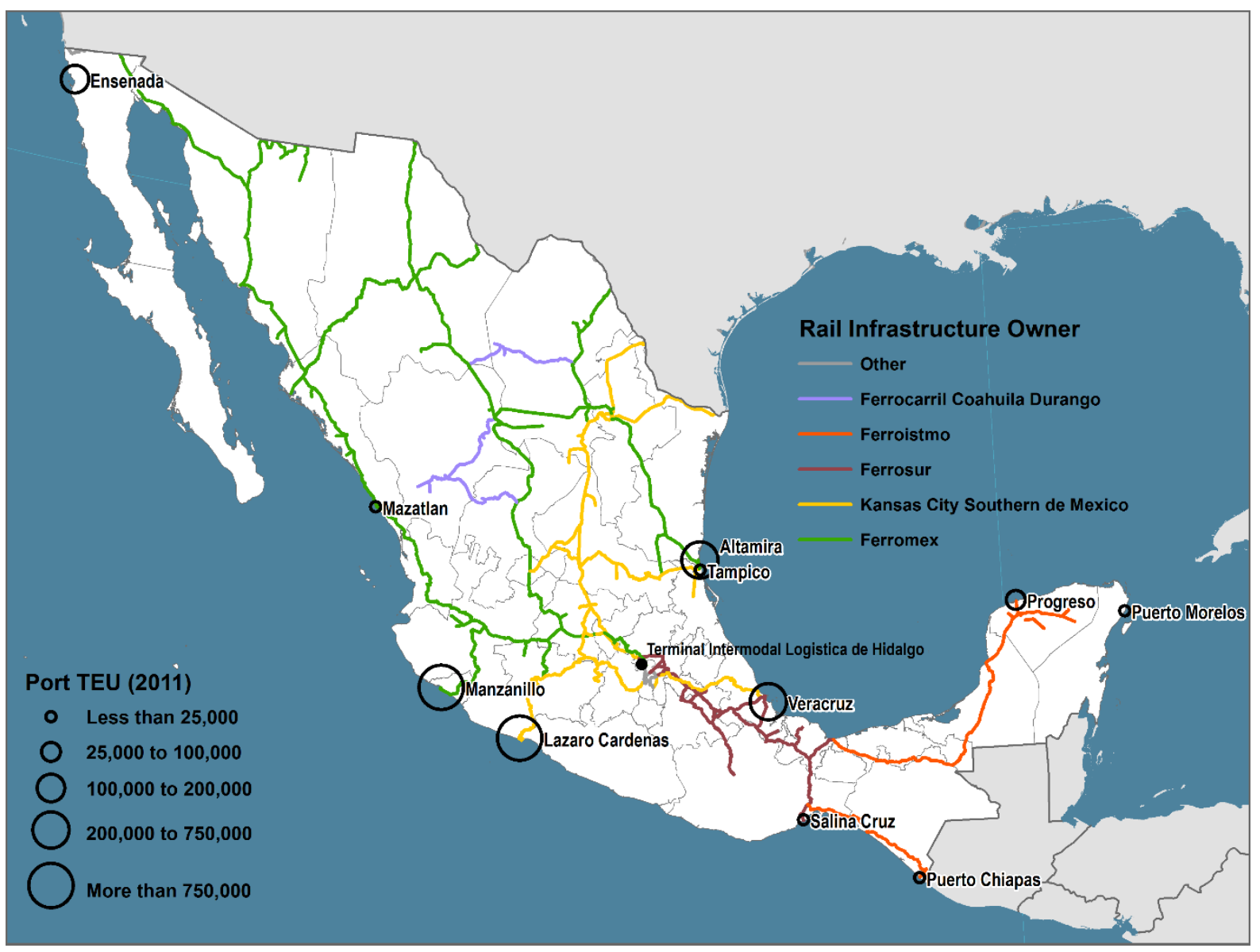

Figure 2: Mexican Container Port Traffic and Ownership of Rail Infrastructure Source: Authors

Prior to 1993 all ports in Mexico were operated by the single national operator PUMEX (Puertos Mexicanos). In 1993 Mexico engaged in an extensive port reform process involving the privatization of terminal operations through concession agreements. During the port reform 64 API (integrated port administrations) were created. The goal was to deregulate and decentralize port administration and planning and to facilitate the privatization of port operations and stimulate private investment under the landlord port authority model. APIs are commercial public enterprises that manage the ports in which private, municipal and state representatives participate. The land managed by the APIs is concessioned from the state. The port law delimits the administrative function and the authority to avoid discretional interventions (Wilmsmeier, 2006).

The role of APIs is very significant as the growth in demand is creating the need for further capacity expansion. Additionally, current developments are important as the first container terminal concessions are currently up for renewal. The latter can have a significant impact on port development and competition prospects depending on the outcomes: either a) 
the continuation of current operators, and/or b) the appearance of new concessionaires in the market.

Port throughput in Mexico has grown substantially since the port reform, but at significantly different rates on each coast. The container traffic on the Pacific coast grew at a higher rate than the Gulf coast, which has led to a shift in the share of the respective maritime ranges. While 68 per cent of Mexico's container traffic was handled on the East coast of the country in 1997, both coasts handled almost equal shares in 2004, and by $201369 \%$ of all containers were moved through ports on the Pacific coast. This is indicative of a growing adaptation of Mexican port operations to Asian supply chains as well as the development of transhipment hubs as carriers progress from a point-to-point to a hub-and-spoke strategy by using ports such as Manzanillo (Wilmsmeier et al., 2014).

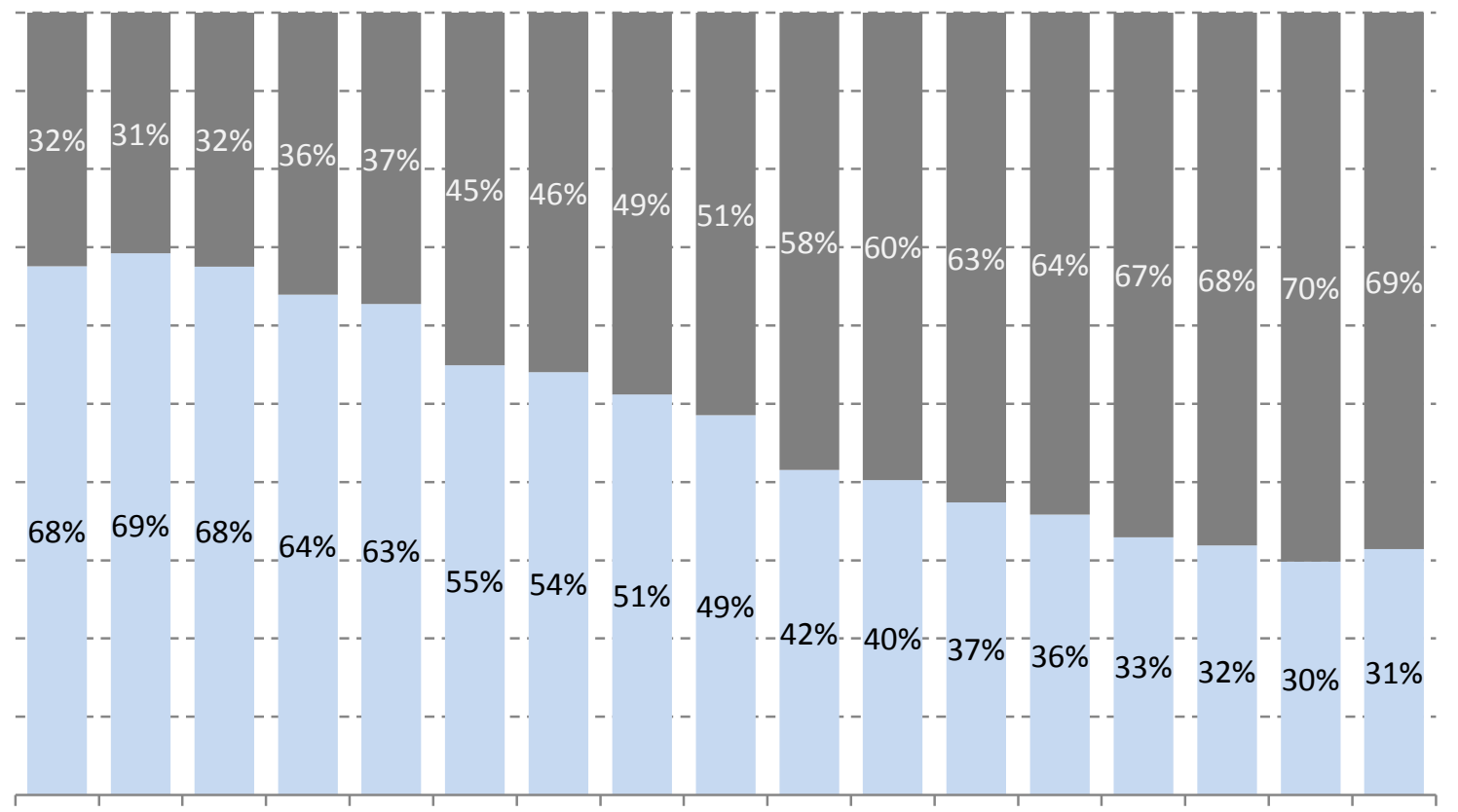

19971998199920002001200220032004200520062007200820092010201120122013

$$
\text { East Coast Mexico (Caribbean) } \square \text { West Coast Mexico (Pacific) }
$$

Figure 3: Mexico share in container traffic Gulf coast vs. Pacific coast, 1997-2013

Source: Authors, based on Mexico Ministry of communication and Transport

The Mexican port system handled 4.9 million TEU in 2013, 14.3\% more than the previous year, and a quintupling since 1997 (Figure 4). Growth rates in the ports of the Pacific coast have been significantly ahead of those on the Gulf coast, which has contributed to the shift in the national container traffic share. 


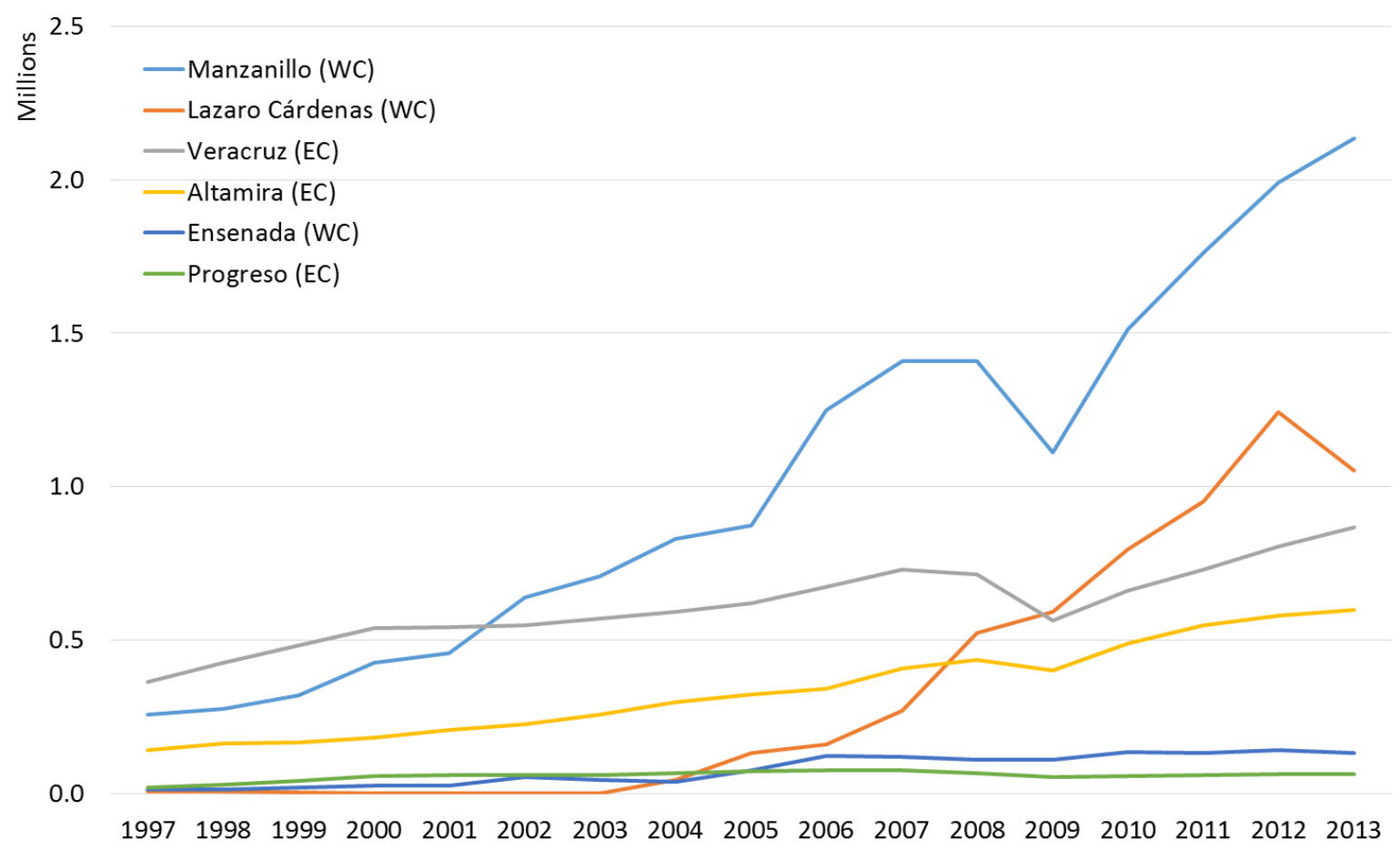

Figure 4: Mexico container throughput main ports, 1997-2013

Source: Authors, based on Mexico Ministry of communication and Transport

HPH is the dominant container terminal operator in Mexico, handling about $50 \%$ of the country's container port throughput in four major terminal facilities (Ensenada, Veracruz, Manzanillo and Lázaro Cardenas). The increase of ship size and liner services in the region is predominately the outcome of a cascading effect where the introduction of larger ships on other routes implies the reassignment of existing ships (and their additional capacity) to new routes (Wilmsmeier, 2013). These vessels put pressure on existing port infrastructure and require an expansion of berth capacity and draft.

Mexico City as an origin or destination accounts for $40 \%$ of all the container cargo handled by $\mathrm{HPH}$, generating about 700,000 TEU annually. In recent years, significant developments have taken place in the northern part of the metropolitan area with several large retailers and manufacturers establishing distribution facilities there.

A legal requirement for the use of customs brokers means that customs procedures are lengthy and double (inspection by both customs officials and brokers). This results in significant time delays for inspections as well as consuming significant terminal space for cargo inspection activities. Customs agents review cargo and attach stickers with Mexican standards. No cargo without a standard sticker will be permitted to leave the port. This activity which is uncommon in other ports around the world impairs the port's capacity and 
operational efficiency. This is a logistics issue that needs to be mitigated, particularly with the replacement of a sticker with an electronic clearance.

The integration of ports and their hinterlands has emerged as an important issue for economic development and in 2011 the federal government set the objective to establish a National System of Logistics Platforms (Sistema Nacional de Plataformas Logísticas). These efforts are supported by the development of a new regulation for multimodal transport and are anticipated to generate better coordination between the different transport modes in national and international transport. The better coordination is hoped to result in higher security, quality, efficiency and competitiveness for multimodal transport, which are key freight distribution concerns in Mexico.

The Mexican port system thus has several key issues to be addressed, such as port development to handle increasing requirements of the maritime sector, the need to improve the agility of customs clearance and the need to more efficiently integrate with the port hinterland.

\section{Case study of the port of Veracruz}

\subsection{Overview}

The port of Veracruz is located on the Gulf coast of Mexico (see Figure 2) and is managed by the port authority APIVER (Administración Portuaria Integral de Veracruz), which oversees the port development planning and manages the concession processes. HPH is the largest container operator in the port, moving $83 \%$ of all containers in its specialized terminal, which it has operated since 1995. Since then the terminal has undergone a significant conversion. However, the current length of the HPH terminal is restricted by an adjacent historical site (Fortaleza de San Juan de Ulúa), resulting in a restriction in the number of ships that can be handled simultaneously at the terminal, which is a strong impediment to its operational effectiveness.

In 2013 the port received calls from 8 shipping lines of which MSC and Hapag Lloyd were responsible for $65 \%$ of all traffic generation. $44 \%$ of the trade handled is with Europe, followed by the Mediterranean (21\%), South America (19\%) and the Caribbean (16\%). However, changes in trade patterns can be observed where the origin of trade is concentrating in fewer locations and the destinations of cargo are diversifying.

The main market for the port of Veracruz is the immediate hinterland represented by the states of Veracruz, Puebla, México and Distrito Federal, which together account for $83 \%$ of the total port hinterland in terms of value. This accounts for 55\% of Mexico's GDP with a 
population of 66.5 million. In these states are the most important national production centers for automotive, chemical, pharmaceutical, textile, beer and coffee.

A significant share of the trade is consumer products and production inputs for the automotive cluster in Puebla and thus requires well-developed logistics services. The port has a strong dependence on a few key customers, such as Volkswagen that moves 600 TEU per month. These customers require specific logistics services, namely a prioritization of cargo on ships and for movements to the hinterland. The activities of the automotive industry for port and logistics development are of high importance as the sector accounted for $6 \%$ of the foreign direct investment, $4 \%$ of the national GDP, $20.1 \%$ of the national manufacturing GDP and $23 \%$ of exports in 2012 (INEGI, 2013). The terminal operator has already introduced a priority discharge system for certain customers, particularly in the automotive industry, that requires certain standards of reliability and specific delivery times of their cargo.

The Veracruz port authority APIVER is planning major port developments. The development of a 26 hectares "Zona de Actividades Logísticas" (ZAL) is an integral part of the port development, aiming to establish port-centric logistics. Significant improvements to the port's rail and road access are planned, as well as a new port terminal and a new intermodal terminal of 26 ha. This development is comparable with efforts to develop portcentric logistics in other parts of the world. Part of the expansion also concerns real estate development (e.g. retail, condos) to take advantage of the tourism appeal of Veracruz, as well as the development of a cruise terminal.

The Centre for Logistics Support and Transports (Centro de Apoyo Logístico al Transporte - CALT) regulates access to the port area via an electronic authorization system and a dedicated highway through customs and the container terminals. It allows monitoring performance such as truck turnaround time in the terminal. The system has a capacity of about 650 trailers per day and also provides basic services to the truck drivers.

Also, APIVER is planning the construction of double-track railway access which will connect the port with the national rail system (FerroSUR, KCS). Today all rail services to ondock and near-dock terminals must access via FerroSUR tracks and must use FerroSUR locomotives, which is creating conflicts of interest when moving competitor's cargoes. The new access with a length of $19.5 \mathrm{~km}$ will give double-track railway access going through the ZAL connecting with FERROSUR/FERROMEX and KCSM. The operating model for the railway bypass is still to be decided and will determine if access will continue to be discriminatory (one carrier) or neutral (performed by the port authority or a company 
appointed by the port authority), and is thus a key factor in the future operational efficiency of inland logistics strategies.

The existing port terminal operator (HPH) would like to bid and get access to a new terminal facility (currently being developed), as the existing terminal is suboptimal and quay docking space is constrained. One proposal to the port authority is a "terminal swap". However, a potential contention exists between APIVER and HPH, because the port authority would like to introduce competition in the container market by offering the new terminal concession to a second operator. The port authority will have to resolve whether to allow the current container terminal operator to switch to the new terminal and thus maintain its strong market position or concession the new terminal to a second operator to introduce more competition in the market. The latter will raise the question whether minimum scale efficiency can be reached with two container terminal operators in the port. On the other hand, the entrance of a second operator might lead to destructive competition or result in no or very low interest from bidders.

\subsection{Inland port development}

The private container terminal operator HPH has pursued an inland port development with an $80 \%$ stake in the Terminal Intermodal Logístico Hidalgo (TILH), which opened in 2012. It is located in the southern part of the state of Hidalgo about $50 \mathrm{~km}$ north of Mexico City, one of the world's largest metropolitan areas with a population of more than 21 million people (see Figure 2 for location).

The TILH site includes a standard greenfield logistics zone of 127 hectares (Zona de Actividades Logísticas Hidalgo) co-located with an intermodal terminal facility covering 53 hectares, with an additional 10 hectares allocated to customs. Securing land was a complex endeavour that took 3 years since the ownership of the rural land was collective and required a process where it was transferred to the state and then to private interests (HPH and Unne). Recognizing the potential of such a facility and its logistics zone for employment and regional development, the public sector contributed by building an access road, a bridge and providing utilities (electricity, water and sewage).

TILH is a grounded intermodal facility where containers are stacked trackside Europeanstyle, which is different from the standard North American chassis-based storage used at most terminals. Grounded operations are better-suited to locations with smaller land area as containers can be stacked. The initial intermodal capacity of the facility is about 220,000 TEU and once all expansion phases are completed, the capacity will increase to above 1 
million TEU. In its current setting, the terminal provides 4 rail sidings of 600 meters directly connected to the rail network of two of Mexico's largest railways, KCSM and FERROMEX. Because of its geography, the Mexico City metropolitan area has a scarcity of large surfaces of flat land, therefore the TILH site required significant modifications (mostly infill and grade adjustments) to make it suitable for intermodal operations. In 2013 the terminal handled 29,000 TEU and activity is expected to reach 70,000 TEU in 2014.

Inland ports can be developed in the hinterland according to different strategies, involving differing motivations, actors, functions and logistics models and locational preferences. They can be built to ease port congestion or for hinterland capture and port competition. They can be designed on a rail-based strategy of generating economies of scale on high-capacity, longdistance links. By contrast, they can be road-based short-distance satellite terminals to ease port congestion or facilitate fast-track customs clearance. A successful inland port must be based on a clear understanding of the value proposition, which will be different at each site. The main value propositions of the TILH facility are modal shift, customs clearance, acting as a load centre and metropolitan accessibility.

Modal shift. Like many developing countries, the share of trucking for inland distribution in Mexico is very high, which is linked with congestion, energy consumption, air pollution and delays. The expectation is that the inland port will support modal shift of a share of the cargo bound to Mexico City to rail. One of the key advantages of the facility is its direct connectivity to both the Pacific and Gulf maritime ranges where HPH operates port terminals. Veracruz on the Gulf side is about $500 \mathrm{~km}$ away while Lázaro Cardenas and Manzanillo on the Pacific side are about $600 \mathrm{~km}$ away. This distance is at the threshold of commercial competitiveness for rail services.

Custom clearance and dwell time. Importers have the option, through bonded deliveries, of having the custom clearance deferred to the inland port instead of at the gateway port. This can lower inspection costs as well as delays. Inland terminals, having abundant storage space, can also offer convenient dwell time, implying that they can partially act as a warehouse for their customers since a container at the inland port can be considered as part of the inventory of a nearby distribution center.

Load centre. As a facility integrated with the maritime ports to which it is linked, TILH acts as a deconsolidation (for imports) and consolidation (for exports) centre. This can be effective to attract and retain customers as well as improving the quality of the transport service since the HPH port terminals and TILH are one functional transport chain. In addition to the inland accessibility from ports on the Gulf and Pacific sides (longitudinal flows), TILH 
has the potential to become a load center for the NAFTA trade (latitudinal flows), which remains dominantly serviced by trucks. Its access to the Lázaro Cardenas - Laredo - Kansas City corridor offers a strategic commercial opportunity.

Metropolitan accessibility. A logistics cluster (intermodal terminal and nearby distribution centers) offers a platform that is better-placed to service a metropolitan area (Mexico City) than direct truck services from port terminals, particularly if well connected to an urban highway system. There are also more opportunities to deconsolidate the cargo in loads that are more suitable to urban demand (high frequency) and driving conditions (congestion).

\subsection{Customs clearance}

Customs operations at TILH began in 2013 using a temporary installation. Currently, the government is preparing to install permanent customs installations. These are expected to commence service by 2015 (via libre, 2014). This underlines the importance of being proactive in developing hinterland intermodal facilities and the weight major customers have in inciting the usage of novel approaches in hinterland logistics.

A key challenge for the exploitation of sites like TILH is to implement ICD characteristics (notably customs clearance) in order to alleviate capacity pressure in the port and issues related to road security. Security issues are an important challenge for clearing customs inland. They particularly relate to robbery and the undervaluation of cargo as a common practice to reduce duties. With a shift from road to rail operations and greater facilitation to provide rail services these risks could be mitigated.

Additionally, customer requirements and preferences for imports vary across continents. Asian importers, mainly retail products, have the tendency to clear customs inland, preferably at the final destination; as noted in section 3, such cargo moves mostly through Pacific ports. On the Gulf Coast, more intermediate products are imported as trade is dominated by intraindustry supply chains; these customers do not have a specific preference about where the cargo is cleared. Therefore, the prominence of the Asian trade on the Pacific coast clearly favours rail activities on the Pacific coast.

\subsection{Rail regulation}

The number of intermodal terminals in Mexico increased from 67 to 81 between 2007 and 2011. These 81 terminals include 17 railway terminals, 18 port terminals, 8 private car terminals and 38 intermodal freight terminals. The current government strategy focuses on strengthening private investment initiatives to promote intermodal cargo transfer. Recently, a number of new terminal projects have been granted. Besides HPH, the Grupo Logístico 
Méxicano S.A. (GLM) also operates a total of 33 terminals, of which 14 are inland and 13 are intermodal terminals at ports. The company has cooperated closely with the railway operator FERROMEX since 2005. Thus the initiative from the government does also have a regulatory incentive aiming at the coordination of private terminal infrastructure development

The share of intermodal transport towards the hinterland varies significantly. For instance, in Lázaro Cardenas $46 \%$ of containerized cargo is moved by rail whereas in Veracruz the figure is only $10 \%$. The port of Veracruz has cooperation agreements with six intermodal terminals: Tracomex, Aguascalientes; Pto. Interior, Guanajuato; SID, Queretaro, Logistik, San Luis Potosi; Ferrovalle Modal, Estado de Mexico. The benefits of TILH in comparison to the above-mentioned terminals stem from the integration of the information system and overall management by one actor.

Since TILH represents a novel intermodal model for Mexico, it is facing the challenge of securing regular rail services to its facility. The first train services started in September 2012. Currently, the main problems to implement rail services at a higher frequency and capacity are the entry barriers to provide rail services, the lack of direct rail access to the port container terminal, the lack of equipment for intermodal rail transport as well as the travel times. For instance, road transport requires 9 hours between Veracruz and Hidalgo compared to 12 hours by rail. The rail access to the terminal is restricted by regulatory, operational and infrastructural factors. This includes the absence of rights to operate rail within the terminal area of the port, due to the existing rail concession agreements. The traditional focus of the rail industry is to move bulk cargoes that require different logistics strategies than containerized cargoes. Thus, the rail industry currently lacks a wider understanding of the customer requirements when moving containerized cargoes.

The railway network in Mexico has been concessioned to private operators, who operate as single operators on specified routes on the network (Figure 2). Thus, the current system limits direct competition on routes and is rather set up under the principle of competition of networks. The Mexican market is distributed by geographic areas, with some regions only served by one carrier. The current system creates entry barriers for new players in a market that has traditionally focused on bulk transport and a low priority is placed on intermodal transport. Thus, the railway sector lacks equipment to satisfy the demand for container transport, particularly if this demand continues to grow with the hinterland strategies being set in place. 
The current structure limits also the access to ports and hence on-rail competition; Veracruz and Tampico are the only ports that are served by two railway operators. The current organization of the railway sector has also resulted in very low levels of investment in railroad infrastructure and the railway network was not expanded over recent years, despite growing demand. Investments are primarily for maintenance of tracks, but not for improvement. Efforts from the federal government focus on the modernization and construction of infrastructure on international routes in order to strengthen international trade and the development of Mexico as a gateway for international trade of the US.

The new rail access is of high importance to improve the intermodal accessibility to and from the port. However, applying the current rail service concession regime would create a monopoly access to the port. Thus, the current challenges in rail access are likely to endure and could be mitigated by equal access rights between Ferrosur and the port in order to facilitate competition in the rail transport market. At the same time there seems to be a need to revise the current railway concession and operating scheme as the sector lacks investment and does not seem to respond effectively to market requirements, such as increased container traffic. One reason might be the lack of competition in each of the regional markets.

\subsection{Cargo security}

The interest in logistics integration with the hinterland is not only driven by operational factors. Recent research shows that the cost of crime and violence to companies in Mexico is among the highest in Latin America (Pérez, 2013). Therefore, security issues play an important role in the focus on new strategies including intermodal rail transport. However, this development of rail services is hampered by entry barriers to provide intermodal rail services and the lack of competition in the market. As a result the terminal operator in Veracruz has responded to the lack of rail services with the creation of a "virtual train" that was discontinued once regular rail services became available in 2013. The service used double trucks, carrying two 40ft containers, which made the capacity of one truck comparable to that of a rail wagon thus maximizing economies of scale in trucking. This service provided a daily rotation of rolling stock and was managed on tollways in convoys to improve security of transport. The "virtual train" initiative was a direct response to market requirements to provide safer, more reliable and integrated services and brought additional benefits over existing road transport solutions in terms of energy consumption and efficiency.

\subsection{Land acquisition}

Securing land for logistics at inland locations is a common challenge in Mexico, where the main land ownership regime is referred to as "Ejido", created from land reform decrees 
issued by the federal government in the 1930s. These decrees provided land areas for agricultural purposes to communities of peasants who needed to work collectively. The goal was a more equitable distribution of wealth.

An Ejido is composed of a set of property lots which belong to individual families and may only be inherited by subsequent family members. It is not a private regime and therefore it is not possible to sell the Ejido land plots individually or in conjunction, unless a very specialized legal process is followed which involves the nullification of the public decrees after obtaining specific government authorization. This process was put in place after the setting of NAFTA that opened the door to a series of foreign investments with the need to secure private land for manufacturing and logistics.

The process of public disincorporation regime into private land ownership for subsequent commercial transactions normally takes years as it also implies obtaining unanimous consensus of the entire peasant community that collectively owns the Ejido at various stages of the process. Mexico, like many Latin American countries, exemplifies the complexity of securing land for logistics, particularly in terms of time.

\section{Applying the conceptual model: drivers and direction of inland port development in Mexico}

The Veracruz case analysed in this paper was an Outside-In inland port development led by the private port terminal operator. In previous research on Outside-In developments (Monios \& Wilmsmeier, 2012), this was found to be a more successful model than initiatives led by the public port authority because the terminal operator's control of container flows makes it better-placed than the port authority to ensure efficient planning and communication as well as the actual physical operations. Like the Venlo, Netherlands case (also developed by $\mathrm{HPH}$ ), the private port terminal operator operates and majority-owns the inland terminal but is not the majority owner of the co-located logistics platform. In this case, the state government helped arrange the land purchase as well as providing some infrastructure and utilities. The site is also connected to more than one port, and particularly, more than one terminal operated by the same operator. Unlike Venlo, however, HPH operates the inland port but does not control the rail services. Also, rail access into the port is constrained by different companies having right of access. These constraints need to be mitigated in order to establish a proper closed loop "extended gate" operation like at Venlo. It means that operational efficiency in the Veracruz case is challenged by a lack of control by a single actor 
managing container flows between the port and inland location, which is one of the primary aims of an ideal Outside-In model.

Operating an "extended gate" system will also require the movement of containers inland under customs control which is required to achieve container flow efficiencies on the rail services. The increase of rail traffic to and from the port will be a prerequisite for further logistics integration at a significant scale and also offer a partial response to overcome security issues in road transport. Railway integration also strengthens the development of ICDs in the hinterland, thus alleviating congestion in the port terminal area caused by competition for space between customs and terminal operations. Port land is of significantly higher value than at the inland terminal and thus requires intensive capacity use to achieve economic efficiency. As customs operations are land consuming and extensive these may be better suited to inland locations.

Previous work underlined that it is challenging for port actors to act inland. Even in Outside-In developments, inland actors are required and the port actor is constrained by institutional issues beyond their control, whether these are related to government regulation (e.g. customs clearance or land acquisition) or industry structures (e.g. the rail or logistics sectors). However, in this case study the institutional setting of inland regions is not strong enough to develop a site independently, therefore impetus was required from the port actor.

The literature review in section 2 revealed that Inside-Out developments tend to be more common in developing countries due to strong institutional settings for regional development. The analysis of the Veracruz case has shown that such institutional settings are not in place in Mexico. Therefore, if inland port development is going to occur, it is more likely to follow the Outside-In model because the global port terminal operators are applying a model developed in other contexts. This suggests that inland freight flows will be determined to some degree by port development strategies rather than the priorities of inland actors. While this means that inland regions may lose potential opportunities to harness economic benefits by capturing trade flows, it increases the likelihood of successful developments based on efficient container flows rather than being distorted by public sector developments without a solid business case. Moreover, while the current case has not yet achieved the full benefits of an ideal Outside-In model by having one actor controlling the inland container flows, it has already been found to be more secure through the benefits of using rail rather than road haulage.

The final point to consider is to what extent the Mexican case compares with the development of intermodal hinterland development in other continents. As transport and 
logistics industries are being expanded worldwide, operations and actors become increasingly integrated through regionalisation processes. China is beginning to follow Europe and North America in using inland ports as levers to reform customs clearance and develop highcapacity intermodal rail shuttle services between ports and hinterlands, requiring significant infrastructure development as well as changes in the rail industry structure (Monios \& Wang, 2013). The USA and China are single countries and Europe operates a customs and currency union, helping to ease the barriers to such intermodal efficiency. In Africa, the institutional difficulties associated with different countries, regulation and infrastructure management have delayed such development (Kunaka, 2013; UNCTAD, 2013). This paper has shown that Mexico is working to overcome such barriers through port and customs reforms, but the rail system remains a challenge, both institutionally and operationally. Finally, this case also echoes the experience of other developing countries as intermodal services are beginning to intrude on what has until now been primarily a bulk railway.

Table 1 summarises the drivers and challenges of directional development in developed and developing countries, drawing on previous literature and the Veracruz case. 
Table 1. Drivers and challenges of directional development in developed and developing countries

\begin{tabular}{|c|c|c|c|c|c|}
\hline & \multicolumn{2}{|c|}{ Inside-Out } & \multicolumn{2}{|c|}{ Outside-In } \\
\hline & & Developed & Developing & Developed & Developing \\
\hline \multirow{8}{*}{ Drivers } & $\begin{array}{l}\text { Reduce port } \\
\text { congestion }\end{array}$ & & & $\mathrm{X}$ & $\mathrm{X}$ \\
\hline & $\begin{array}{l}\text { Port competition } \\
\text { through hinterland } \\
\text { capture }\end{array}$ & & & $\bar{X}$ & $\mathrm{X}$ \\
\hline & $\begin{array}{l}\begin{array}{l}\text { Economic } \\
\text { development }\end{array} \\
\end{array}$ & $\mathrm{X}$ & $\mathrm{X}$ & & \\
\hline & $\begin{array}{l}\text { Access to logistics } \\
\text { services }\end{array}$ & & $\mathrm{X}$ & & \\
\hline & $\begin{array}{l}\text { Easier/cheaper } \\
\text { customs processes }\end{array}$ & & $\mathrm{X}$ & & $\mathrm{X}$ \\
\hline & $\begin{array}{l}\text { Lower transport costs } \\
\text { by consolidation on } \\
\text { intermodal route }\end{array}$ & $\mathrm{X}$ & $X$ & $\mathrm{X}$ & $\mathrm{X}$ \\
\hline & $\begin{array}{l}\text { Reduce emissions } \\
\text { through modal shift }\end{array}$ & $\mathrm{X}$ & $\mathrm{X}$ & & \\
\hline & Security & & $\bar{X}$ & & $\mathrm{X}$ \\
\hline \multirow{5}{*}{ Challenges } & $\begin{array}{l}\text { Lack of coordination } \\
\text { in management of } \\
\text { transport chain }\end{array}$ & $\mathrm{X}$ & $\mathrm{X}$ & & \\
\hline & $\begin{array}{l}\text { Difficulty for port to } \\
\text { act inland }\end{array}$ & & & $\mathrm{X}$ & $\mathrm{X}$ \\
\hline & $\begin{array}{l}\text { Financial viability of } \\
\text { rail service }\end{array}$ & $\mathrm{X}$ & $\mathrm{X}$ & $\mathrm{X}$ & $\mathrm{X}$ \\
\hline & Land acquisition & & & $\mathrm{X}$ & $\mathrm{X}$ \\
\hline & Rail regulation & & $\mathrm{X}$ & & $\bar{X}$ \\
\hline
\end{tabular}

These findings are discussed in detail in section 6.2. While the Veracruz case followed the Outside-In model in most respects, the new additions to the model from this case study were the role of cargo security as a driver and the challenge posed by a lack of rail regulation. The difficulty of land acquisition was also a significant challenge in this case.

\section{Conclusions and research implications}

Regionalisation processes have in the past been categorised for the most part as being imposed on ports, as ports traditionally have rarely had the motivation or the competence to act directly in the hinterland. As a result, regionalization strategies pursued by port actors have been insufficiently addressed in previous research. While the directional model 
highlights the difficulties of port actors extending their influence beyond the port perimeter, some ports have managed to do so. This paper has taken a single Outside-In case in detail, to examine a port's hinterland development strategy from spatial and institutional perspectives. The perspectives provided by the case study of Veracruz underlined the problems faced when developing an inland port in Mexico; these findings have applications not just to the wider freight context in the region, but also to other developing countries looking to modernise their logistics systems.

\subsection{Implications for policy and managerial practice}

Growth at the port of Veracruz has resulted in the container terminal reaching its operational capacity limits, with the port also having to respond to external pressures in its hinterland such as customer expectations for logistics services, supply chain security and infrastructure restrictions. Two strategies have emerged to mitigate this situation. First, a public port authority strategy represented by the port expansion plan, including the development of a port-centric logistics zone to attract new services and industry close to the port. Second, a private port terminal operator strategy from the main terminal operator to develop its own inland port.

The inland port initiative faces challenges familiar to other developments elsewhere, as it is dependent on regionally monopolized rail services and setting a customs facility at the terminal was challenging given the current customs regulation and the relevant security issues in the transit from the port to the terminal. The federal government is trying to strengthen the development of intermodal terminals and also to improve current regulation. However, it is not clear if the new regulation will also facilitate inland customs clearance and thus enable the intermodal terminal to achieve its goal as a fully functional ICD. From the private investor perspective, the land acquisition process presents barriers to effective inland terminal development.

Consequently, the national plan for location of logistics platforms, currently under development, will provide a possibility to further align the interests of the public and private sectors. In this context, empirical evidence underlines that securing land to develop intermodal and logistics activities is a complex task that requires to be further streamlined. This would enable private actors, such as terminal operators, to further invest and support development of the physical and operational requirements of hinterland services. The requirements of developing better integrated inland transport chains needs to be further acknowledged, since on many occasions deficiencies in the interactions between actors of 
different modes and jurisdictions were related to substantial constraints. For Veracruz, it was underlined that the state of relations with rail operators was a particularly salient issue in terms of connectivity to on-dock rail yards and the provision of dedicated rail services to the hinterland. The lesson for similar developments is to address such issues as early as possible rather than focusing solely on real estate development.

\subsection{Contribution to scholarly knowledge}

The port terminal operator Outside-In hinterland development strategy is a model that has also been observed in other regions in the world, such as Rotterdam and Barcelona in Europe and Tianjin and Ningbo in China. The institutional structure of the North American freight system means that Outside-In developments are rare, while both operational and institutional weaknesses in Africa limit the effectiveness of ports being proactive. A number of inland ports developed in China in recent years provide evidence of both Outside-In and Inside-Out developments, based on major expansions of the transport and logistics industries and increasing competition between seaports. Applying the directional model to Mexico has revealed the emergence of a hinterland integration model recognisable in Europe, while at the same time exhibiting potential for greater landbridge development to traffic generators in the United States, thus following the existing North American model. However, a more effective system will require the resolution of policy and institutional challenges identified in this research, thus preventing, in the short term at least, a more extensive process of port regionalisation.

Previous cases have shown that the major drivers of Outside-In inland port development were port congestion and competition for overlapping hinterlands. Constraints relate primarily to the institutional difficulties for port actors to act beyond the port perimeter, as well as operational inefficiencies threatening the financial viability of port rail shuttles familiar to intermodal operators across the world, but these will tend to manifest in specific ways depending on the particular rail system. Land acquisition is also a problem for OutsideIn models because of planning and zoning issues and even a lack of suitable sites, as was found in the Hidalgo case. An Inside-Out development led by cities and regions rarely has this problem because either the land is provided or the purchase is subsidised or otherwise incentivised with favourable planning conditions. The major constraint of Outside-In development in this case was not only rail operations but rail regulation, which can be added to the model as an essential element to be resolved if pursuing such a strategy. Reform of rail regulation has been an essential prerequisite for intermodal transport development in both the 
USA and Europe. On the other hand, a key driver of Outside-In inland integration was found in the Mexican case to be security. As previous research was focused primarily on developing countries, this driver was perhaps overlooked, but it can thus be identified as a new driver of the directional model, especially in developing countries.

\section{Acknowledgements}

The authors would like to thank Jorge Lecona and others at HPH for their assistance in providing background information for the paper. All errors remain our own.

\section{References}

Barke, M. 1986. Transport and Trade; Conceptual Frameworks in Geography, Edinburgh: Oliver \& Boyd.

Beresford, A. K. C., Gardner, B. M., Pettit, S. J., Naniopoulos, A., Wooldridge, C. F., 2004. The UNCTAD and WORKPORT models of port development: evolution or revolution? Maritime Policy \& Management, 31, 93-107.

Bichou, K., Gray, R., 2005. A critical review of conventional terminology for classifying seaports. Transportation Research Part A: Policy and Practice, 39, 75-92.

Bird, J. 1963. The Major Seaports of the United Kingdom. London: Hutchinson \& Co.

Cullinane, KPB and Wilmsmeier, G. 2011. The Contribution of the Dry Port Concept to the Extension of Port Life Cycles. In: Böse, J. W., ed., 2011. Handbook of Terminal Planning. New York: Springer.

De Langen, P. W. and Chouly, A., 2004. Hinterland access regimes in seaports. European Journal of Transport and Infrastructure Research, 4, 361-80.

Frémont, A., Soppé, M., 2007. Northern European range: Shipping line concentration and port hierarchy. In Ports, Cities and Global Supply Chains, Edited by: Wang, J, Olivier, D, Notteboom, T and Slack, B. 105-120. Aldershot: Ashgate.

Hayuth, Y. 1981. Containerization and the load center concept. Economic Geography, 57: $160-176$.

Hayuth, Y., 2007. Globalisation and the port-urban interface: conflicts and opportunities. Ports, Cities and Global Supply Chains eds. J. Wang, D. Olivier, T. Notteboom, B. Slack. Aldershot, Ashgate.

Heaver, T., Meersman, H., Moglia, F., Van de Voorde, E., 2000. Do mergers and alliances influence European shipping and port competition? Maritime Policy \& Management, 27, 363-373. 
Heaver, T., Meersman, H., Van de Voorde, E., 2001. Co-operation and competition in international container transport: strategies for ports. Maritime Policy \& Management, 28, 293-305.

Hoyle, BS. 1968. East African seaports: an application of the concept of 'anyport'. Transactions \& Papers of the Institute of British Geographers, 44.163-183.

Jacobs, W., Notteboom, T., 2011. An evolutionary perspective on regional port systems: the role of windows of opportunity in shaping seaport competition. Environment and Planning A. 43 (7), 1674-1692.

Kunaka, C., 2013. Dryports and trade logistics in Africa. In: Bergqvist, R., Wilmsmeier, G., Cullinane, K.P.B. (Eds.) (2013). Dry ports - A Global Perspective: Challenges and Developments in Serving Hinterlands. 83-108. Farnham: Ashgate.

Monios, J., Wang, Y., 2013. Spatial and institutional characteristics of inland port development in China. GeoJournal. 78 (5): 897-913.

Monios, J and Wilmsmeier, G. 2012. Giving a direction to port regionalisation. Transportation Research Part A: Policy and Practice, 46: 1551-1561.

Monios, J., Wilmsmeier, G., 2013. The role of intermodal transport in port regionalisation. Transport Policy. 30, 161-172.

Ng, A.K.Y. and Cetin, I.B. 2012. Locational characteristics of dry ports in developing economies: some lessons from Northern India'. Regional Studies 46(6): 757-773

Ng, A.K.Y, F. Padilha, and A.A. Pallis 2013. Institutions, bureaucratic and logistical roles of dry ports: The Brazilian case. Journal of Transport Geography, 27, pp.46-55.

Instituto Nacional de Estadística y Geografía (2013). La industria automotriz en México 2013. México : INEGI, DR.

Notteboom, T., 2008. Bundling of freight flows and hinterland network developments. The Future of Intermodal Freight Transport eds. R. Konings, H. Priemus, P. Nijkamp, pp. 66-88. Cheltenham, Edward Elgar.

Notteboom, T. E. 2009. Path dependency and contingency in the development of multi-port gateway regions and multi-port hub regions. In: Notteboom, T., Ducruet, C., de Langen, P., (Eds.). Ports in Proximity; Competition and Coordination Among Adjacent Seaports. Ashgate: Aldershot.

Notteboom, T., de Langen, P., Jacobs, W., 2013. Institutional plasticity and path dependence in seaports: interactions between institutions, port governance reforms and port authority routines. Journal of Transport Geography. 27, 26-35.

Notteboom, TE and Rodrigue, J. 2005. Port regionalization: Towards a new phase in port development. Maritime Policy \& Management, 32: 297-313.

Notteboom, T. E., Rodrigue, J-P., 2009. Inland terminals within North American \& European Supply Chains. In: UNTAD, Transport and Communications Bulletin for Asia and the Pacific No. 78: Development of Dry Ports. New York: UNESCAP 
Notteboom, T. E., Winklemans, W., 2001. Structural changes in logistics: how will port authorities face the challenge? Maritime Policy \& Management, 28, 71-89.

Olivier, D. and Slack, B. 2006. Rethinking the port. Environment \& Planning A, 38 (8) pp.1409-1427.

Pérez Salas, G. 2013. Seguridad de la cadena logístics terrestre en América Latina. Serie de Recursos Naturales e Infraestructura No. 161. ECLAC. Santiago. Chile.

Rimmer, PJ. 1967. The search for spatial regularities in the development of Australian seaports 1861 - 1961/2. Geograkiska Annaler, 49 pp.42-54.

Rodrigue, J-P, J. Debrie, A. Fremont and E. Gouvernal (2010) "Functions and Actors of Inland Ports: European and North American Dynamics", Journal of Transport Geography, Vol. 18, No. 4, pp. 519-529.

Schaetzl, L. 1996. Wirtschaftsgeographie 1 - Theorie, 6th edition. UTB, Paderborn.

Slack, B. and Frémont, A., 2005. Transformation of Port Terminal Operations: From the Local to the Global. Transport Reviews, 25, 117-130.

Taaffe, EJ, Morrill, RL \& Gould, PR. 1963. Transport expansion in underdeveloped countries: a comparative analysis. Geographical Review, 53 (4) pp.503-529.

UNCTAD, 1992. Development and improvement of ports: the principles of modern port management and organisation. Geneva, Switzerland: UNCTAD.

UNCTAD, 2013. The way to the ocean; transit corridors servicing the trade of landlocked developing countries. Geneva, Switzerland: UNCTAD.

Van der Horst, M. R., De Langen, P. W., 2008. Coordination in hinterland transport-chains: a major challenge for the seaport community. Maritime Economics \& Logistics. 10 (1-2), 108129.

Van der Horst, M. R., Van der Lugt. L. M., 2009. Coordination in railway hinterland chains: an institutional analysis. Paper presented at the International Association of Maritime Economists (IAME) conference, Copenhagen, June 2009.

Van der Horst, M. R., Van der Lugt, L. M., 2011. Coordination mechanisms in improving hinterland accessibility: empirical analysis in the port of Rotterdam. Maritime Policy \& Management. 38 (4), 415-435.

Van Klink, H. A., 1998. The port network as a new stage in port development: the case of Rotterdam. Environment and Planning A. 30 (1), 143-160.

via libre (2014). Sedeco busca recursos para Aduana, en el Puerto Seco. http://www.diariovialibre.com.mx/sedeco-busca-recursos-para-aduana-en-el-puerto-seco/ (accessed 23 June 2014).

Wilmsmeier, G., 2006. Evolución de las reformas en los puertos de Argentina, Chile y México. Unpublished working paper. The World Bank. 
Wilmsmeier, G., 2013. Liner Shipping Markets, Networks and Strategies. The implications for port development on the West Coast of South America. The case of Chile, ITF Discussion Paper No 2013-22, November 2013

Wilmsmeier, G., Monios, J., Lambert, B., 2010. Observations on the regulation of "dry ports" by national governments. Paper presented at the annual conference of the International Association of Maritime Economists (IAME), Lisbon, July 2010.

Wilmsmeier, G., Monios, J., Lambert, B., 2011. The directional development of intermodal freight corridors in relation to inland terminals. Journal of Transport Geography, 19, 13791386.

Wilmsmeier, G., Monios, J., Pérez-Salas, G., 2014. Port system evolution: the case of Latin America and the Caribbean. Journal of Transport Geography. 39: 208-221 